\title{
Influence of Visual Support Media in Developing Expressive Language and Logical Thinking of Children Aged 4-5 Years in Inclusion Kindergarten Sidoarjo District
}

\author{
Nur Anisah ${ }^{1 *}$, Budi Purwoko ${ }^{2}$, Najlatun Naqiyah ${ }^{3}$ \\ Primary Education, Postgraduate, Universitas Negeri Surabaya
}

\begin{abstract}
The research objectives were to (1) examine the effect of visual support media on the development of expressive language and logical thinking of children aged 4-5 years in inclusion kindergarten; (2) examining the effect of visual support media on the development of language expression and logical thinking in children aged 4-5 years in inclusive kindergartens; Type and quantitative research design with a quasi-experimental design type of non-equivalent control group. The sample used in the study was Kindergarden Diti School class A1 with 15 students and class A2 with 10 students as the experimental class; and TK Batik class A1 15 students and class A2 10 students as the control class. Data collection techniques using tests and observations. Data analysis techniques used analysis of variance (ANOVA) and MANOVA. The results showed that the SPSS output obtained a significance probability value $<0.05$, so it could be concluded that Ho was rejected and H1 was accepted, meaning (1) there was a significant influence between visual support media on expressive language development and logical thinking in children aged 4-5 years in Inclusion Kindergarten. Future research is expected to test media and educational aids that can develop expressive language and logical thinking.
\end{abstract}

Keywodrs:- Visual Support Media, Expressive Language, Logical Thinking, Early Childhood.

\section{INTRODUCTION}

Early childhood (0-6 years) is a period of development and growth that is very decisive for children in the future or it is also called the golden age as well as a very critical period that determines the stage of growth and subsequent development of the child (Suyadi, 2013). Berk (in Yuliani, 2013) said that at this time the process of growth and development in various aspects was experiencing a rapid period in the development of human life.

Language development, which is one of the aspects that must be developed in Kindergarten, aims to enable children to express their thoughts through simple language appropriately, be able to communicate effectively and generate interest in children's language. Children who are educated in kindergarten are expected to be able to express opinions to others and have conversations with peers or adults (Kemendiknas, 2010). According to Santrock (2008) language is a form of communication, whether it is spoken, written or a sign based on a symbol system. All human languages are generative (created). Creation is not limited to the ability to produce an infinite number of meaningful sentences using a set of words and rules. This quality makes language a very creative activity.

The most recent form of education today is inclusive education. Inclusive education is an educational concept that represents all aspects related to openness in accepting children with special needs to obtain basic rights as citizens and can be a strategy in promoting universal education that is effective because it can create schools that are responsive to the various actual needs of children and society (Divine, 2013). The government is currently promoting inclusive education for primary, secondary education and on this basis it is based on Permendiknas Number 70 of 2009 in which there is a regulation which states that every province and district / city is obliged to provide inclusive education.

Realizing this, the researchers raised this inclusion material so that many more early childhood education institutions would make their institutions an inclusive school in which there are general children and a small number of children with special needs. Researchers want to contribute so that inclusive school educators have a method or way to provide classroom learning where it is mixed between general children and some children with special needs. There are still many inclusive school educators who do not have the knowledge and experience in handling general children who are mixed with special children so that it makes researchers excited to conduct research in order to be able to provide new knowledge for educators in inclusive schools in carrying out classroom learning, so that learning can run according to its objectives . Researchers focused on children aged 4-5 years because the number of children in terms of speaking vocabulary was still limited and lacked understanding in answering teacher questions. This is because the media used is less varied, precise, and unattractive. To overcome this, the researcher will examine the development of expressive language as a solution in the process of developing children's language that can affect their future learning (Freud, 2012). 
Language development includes listening, speaking, listening, reading and writing. Language is a means of communication to convey thoughts, feelings and meanings to other people if this is assisted by using interactive media and also supported by environmental conditions and families who are good at a sensitive age who are still able to generate language skills. The environment affects children's language development, as evidenced by the environment of care for more educated families that is much richer in vocabulary than children who are cared for by less well-educated and less well-educated families. The reason is that they do not have time to develop active communication with their children (Otto, 2015).

Vygotsky(in Otto, 2015) the most important thing in the learning process is language. According to him, there is a close relationship between language development and cognitive development. Every individual needs language to process thoughts, symbolize and describe the world. Many claim that language is a cultural tool.Besides the development of expressive language which is closely related to pehe cognitive development of early childhood is also very important to be developed. The cognitive development of early childhood is divided into several developmental scopes, the first is learning and problem solving, namely being able to solve simple problems in everyday life in a flexible and socially acceptable way and to apply knowledge or experience in a new context. Second, logical thinking, namely recognizing various differences, classifications, patterns, taking initiatives, planning, and recognizing cause and effect. The third is symbolic thinking, namely recognizing, mentioning, and using the symbol numbers 1-10, recognizing the alphabet, and being able to represent various objects in the form of images (Permendikbud No.137 of 2014). In thinking logis in children aged 4-5 years there are several problems that need to be considered so as not to hamper the process of developing children's logical thinking, including giving the opportunity to make the child the center of learning activities so that the child does not just listen to the teacher but the teacher gives the child the opportunity to expressing the desire or willingness of early childhood, encouraging children to learn actively.

Logical thinking is a development in which stages are determined in abstract processes in Piaget's cognitive development phase. Yaman explained that with the development of logical thinking (Logical Thinking Skills), learners solves the problem by doing various mental practices or reaches principals or rules by doing some abstraction and generalization (Yaman, 2005). Think logis in children aged 4-5 years there are several problems that need to be considered so as not to hamper the process of developing children's logical thinking, including giving the opportunity to make the child the center of learning activities so that the child does not just listen to the teacher but the teacher gives the child the opportunity to expressing the desire or willingness of early childhood, encouraging children to learn actively.
Efforts to improve the development of expressive language and logical thinking can be made through various media including images, photos and even ourselves as media. The media for children's visual support is more familiar to use by institutions that deal with children with autistic disabilities and it turns out that this media is able to develop language and cognitive understanding of children with autism. Researchers think that if children who experience obstacles can get progress with these media, of course for general children it will be better.

Researchers made observations in January 2019 in twoKindergartenInclusion, Sidoarjo District, Sidoarjo Regency and it was found that some children in one class are not yet able to speak expressively and think logically, and there are children with special needs which of course require separate techniques to handle them. The use of less attractive learning media causes children to be uninterested in paying attention to teachers, especially children with special needs that are increasingly distracted. Therefore this study will use learning media with the understanding that everything that can be used to transmit messages (learning materials so that it can stimulate the attention, interests, thoughts, and feelings of students in learning activities to achieve learning objectives and learning activities).Learning resources or physical vehicles that contain instructional materials in the child's environment that can stimulate children to learn, on the other hand, says that learning media at the learning orientation stage will greatly help the effectiveness of the learning process in addition to arousing children's motivation and interest.Daryanto, 2015)

The opinion of Susilana and Riyana (2009: 10) Learning media is very appropriate considering the benefits it has, namely making concrete concepts that are still abstract. Good learning activities will certainly attract the interest of children and children don't feel bored by using learning media. Learning media is divided into three, namely audio media, visual media and audio visual media (Fadillah, 2014). This research uses visual media. Visual media is a medium that prioritizes vision. In certain situations, visual media is better used than audio media. What's more with a class where there are children with special needs, especially children with autistic disabilities, of course, visual media is very helpful for them.

Media for children's visual support is very simple and simple. There are three things in this children's visual support media, namely Body Language. Body language includes facial expressions, gestures. In communicating, natural body language affects the effectiveness of conveying messages. Natural Environmental Cues, a child's visual support media that is naturally available, has not been widely realized, such as the arrangement of furniture, the location of activities between rooms, classroom decorations, etc. Traditional Tools for Organitation and Gifing Information in the form of daily plans, calendars, menu notes, maps, checkbooks etc. Media The visual support media for children is very simple and easy for the 
teacher to apply so that it makes the learning atmosphere more attractive,

Previous research that is relevant to this research is Choirunisa Nirahma's (2012) research entitled "Methods of children's visual support media in learning children with autism." Tools for Organitation and Giving Information "in terms of communication, understanding and independence. This study used a qualitative approach with the research subjects of teachers or therapists in two different institutions. This study inspired researchers to try children's visual support media to be applied to children or students in inclusive schools, especially Kindergarten A, who still experience obstacles in expressive development and logical thinking.

Research by Kadek Yuli Antari (2016) with the title Application of Visual, Auditory, Kinesthetic Learning Models assisted with Image Media to improve the cognitive ability of the concept of numbers. This type of research is a classroom action research with two cycles, the research subjects of Kindergarten B students are 25 children. This research shows that there is an increase in the cognitive ability of children's number concepts after the application of the learning model (VAK) assisted by image media. This is the same as research that raises cognitive enhancement material with visual, auditory, and kinesthetic learning where researchers also use body language for learning and this study uses image media for assistance just like researchers use traditional tools for organizing and giving information.

The purpose of this research is (1) knowing the effect of visual support media on the development of expressive language for children aged 4-5 years in Inclusion Kindergarten, Sidoarjo District; (2) to determine the effect of visual support media on the logical thinking skills of children aged 4-5 years in Inclusion Kindergarten, Sidoarjo District; and (3) determine the effect of visual support media on the development of expressive language and logical thinking skills of children aged 4-5 years in Inclusion Kindergarten, Sidoarjo District.

\section{THEORETICAL FRAMEWORK}

\section{$>$ Virtual Support Media}

Visual support media is a medium that describes what we see everyday to support communication, such as body language or body gestures. It can also be a medium that is created to support individuals who may have difficulty understanding something (Hayes, 2010). Children's visual support media are used to represent daily needs as a basis for communication using simple real objects. Media in the form of images, and real objects to represent both real world concepts and real abstract, the use of visuals has been shown to reduce symptoms associated with cognitive disorders, communication, and social disabilities, especially for individuals with autism disorders (Hayes, 2010).
According to Twatchman in Savner and Myles (2003), children's visual support media makes it easier for children to help them improve their understanding of the environment and time. Children's visual support media are anything that is used to improve communication with the help of body movements and gestures as well as objects that are around us. If a student is verbal or non verbal, the child's visual support media can help students express themselves better where the main goal is to improve student understanding.

\section{$>$ Expressive Language}

According to Mustakim (2005), expressive or productive language skills and abilities in Kindergarten age show children like to ask questions about new things, use language according to situations with the right reasons, and actively talk about new things. Another opinion expressed byBromley (in Dhieni, 2006) states that speaking ability is an expression in the form of words. Some are receptive (understood and accepted) and expressive (stated). Examples of expressive language are speaking and writing down information to communicate with others.

Steinberg and Gleason in Suhartono (2005) are included in combinatorial development where the child is able to speak regularly and in a structured manner, the conversation can be understood by others and the child is able to respond both positively and negatively to the conversation of the interlocutor. According to Harris in Tarigan (2008) language skills have four components, namely: 1) listening skills; 2) speaking skills; 3) reading skills; 4) writing skills. Every skill is closely related in acquiring language skills. In childhood we learned to listen to the language, then speak, after that we learned to read and write.

Suhartono (2005) states that children's speech is the delivery of a specific purpose by uttering language sounds so that the sounds can be understood by those who are present and hear their surroundings. The sound of a baby's crying actually also has a specific purpose, maybe it calls its parents, maybe it's cold, maybe it's hungry, maybe it's thirsty and so on. Almost all the sounds that children say have a specific purpose, even though these sounds are not words or sentences. So what is meant by child talk has a broader meaning with the meaning of speaking. If speaking is more interpreted as the pronunciation of language sounds that can be understood by the interlocutor, but children's speech is more interpreted by the sounds spoken by the child, both language sounds and sounds that are not language but spoken by the child's speech tool.

\section{Logical Thinking Ability}

Suminah (2013) states that logical thinking is knowing various differences, classifications, patterns, initiative, planning, and recognizing cause and effect which is translated into the basic competencies of knowing the objects around them (names, colors, shapes, sizes, patterns, properties, sounds, texture, function, and other characteristics) and convey about what and how the objects around him are familiar (name, color, shape, size, pattern, 
nature, sound, texture, function and other characteristics) through various works .

Strydom (2010) defines logical thinking by stating that logical thinking is thought related to cause and effect, in which there is a change in meaning where it is part of thinking. Logical thinking means following a series of ideas or ideas. According to Yaman (2005) states that logical thinking is an image of the ability in which the stages are determined in the abstract process in Piaget's cognitive development phase. Yaman explains that with the ability to think logically, learners solves the problem by doing various mental practices or reaches principals or rules by doing some abstraction and generalization.

\section{RESEARCH METHOD}

This research uses an experimental quantitative approach. Experimental quantitative research is a research method used to find the effect of a treatment or manipulation on other variables under conditions controlled by the researcher (Sugiyono, 2010). This study aims to examine specific populations or samples, random sampling, data collection using research instruments, quantitative and statistical data analysis with the aim of testing a predetermined hypothesis. This type of research is a quasiexperimental with a nonequivalent control group design pattern.

\begin{tabular}{|c|c|c|c|}
\hline Class & Pretest & Treatment & Posttest \\
\hline Experiment & O1 & $\mathrm{X}$ & $\mathrm{O} 2$ \\
\hline Control & $\mathrm{O} 3$ & $\mathrm{C}$ & $\mathrm{O} 4$ \\
\hline
\end{tabular}

Table 1:- Nonequivalent Control Group Design

Information:

O1 : Initial test in the experimental group

$\mathrm{O} 2$ : The final test in the experimental group

$\mathrm{X}$ : Subjects were asked to do the sociodrama method

C : Subject not given treatment

O3 : Initial test in the control group

O4 : The final test in the control group

The research subjects were students in the 4-5 year age groupBatik Kindergarten and students in the 4-5 year age group of Dity Permata Subdistrict Kindergarten, Sidoarjo Regency, totaling 50 students. Collecting data in this study using the type of systematic observation, in this study the observation is used to collect data on language development and socio-emotional development of children before and after the implementation of learning with the sociodrama method.This observation guideline before conducting the research validation to the experts first. This study involved 2 teachers as observers. Based on the scores obtained from the two observers, then the average score of all observers. Observations were made using the same research instrument in the experimental group and the control group
Prior to data analysis, the researcher conducted a validity test and a reliability test which aimed to determine the feasibility of an instrument. The data collected from the results of the distribution of the instruments were then analyzed using the normality test and the homogeneity test. After that, the hypothesis is tested.

\section{RESULTS}

This study aims to examine the influence of visual support media on the development of expressive language and the ability to think logically in children aged 4-5 years in Kindergarten group A, inclusive schools, Sidoarjo District, Sidoarjo Regency. The sample in this study consisted of four Kindergarten institutions. -Children, two institutions as the experimental group and two institutions as the control group. This research was conducted in July November 2020. Researchers used the experimental research design pattern (Quasi Experiment Design) with a nonequivalent control group experimental design.

The research activity begins with making preliminary observations in the two groups of Kindergarten Dity Permata and Kindergarten Batik regarding the development of expressive language and the ability to think logically in children, this aims to measure the level of expressive language development and the ability to think logically in Kindergarten children. -Children of group A inclusion school, Sidoarjo District, Sidoarjo Regency. The next step is to provide treatment to the experimental group. The treatment in the form of visual support media was given 3 times a week for 4 weeks, so that the total treatment given was 12 times. Meanwhile, the control group continued to follow routine classroom activities as planned by the educators / teachers at each respective institution.

The next step is to make final observations in the two groups, this is done with the aim of knowing the child's ability in terms of developing expressive language and the ability to think logically in children after treatment, after obtaining the results of the final observation data, the next step is to test the hypothesis.

\section{Results of Expressive Language Development in the Control and Experimental Groups}

The first stage, observing two groups (experiment and control) to measure expressive language development, the teacher conditions the child by positioning the children comfortably, the teacher introduces all the pictures of various kinds of fruit by showing the labels on each picture. Second stage on The teacher invites communication by showing pictures, the teacher divides into 3 groups, the teacher asks the children to name the objects shown by the teacher, asks the children to group pictures according to color, shape, size The teacher invites the children to sort patterns based on color. The third stage, the two groups were re-observed to measure expressive language development. The fourth stage here is the comparison of the mean value of the experimental group and the control group using a statistical analysis difference test. 
This study provides treatment (treatment) which is carried out only in the experimental group, for 12 days (12 times) so that the total treatment (treatment) given is 12 times. The comparison of the average score for expressive language development in this study is as follows:

\begin{tabular}{|c|c|c|c|c|}
\hline Variable & Group & N & Mean & Information \\
\hline \multirow{2}{*}{$\begin{array}{c}\text { Expressive language development } \\
\text { (Pretest) }\end{array}$} & Control & 15 & 2.3067 & Enough \\
\cline { 2 - 5 } & Experiment & 15 & 2.4667 & Enough \\
\cline { 2 - 5 } & Total & 30 & 2,3867 & Enough \\
\hline \multirow{2}{*}{$\begin{array}{c}\text { Expressive language development } \\
\text { (Posttest) }\end{array}$} & Control & 10 & 3,0400 & Well \\
\cline { 2 - 5 } & Experiment & 10 & 3,7000 & Very good \\
\cline { 2 - 5 } & Total & 20 & 3.3700 & Very good \\
\hline
\end{tabular}

Table 2:- Development of the expressive language of the Control and Experimental Groups

Source: Data processed by the author, 2020

Based on table 2, it is known that the results of expressive language development (posttest) in the control group have an average value of 3.0400 which is in the category "Well" Expressive language development. Meanwhile, the results of the post-test expressive language development in the experimental group had an average value of 3.7000 which was included in the assessment of children having expressive language development in the "Very Good" category after doing visual support media.

Based on the description above, the increase in the average value of the experimental group in visual support media activities was greater than the control group, this was because the experimental group received treatment in the form of visual support media that had been designed to stimulate the development of expressive language, measured the child's final ability to communicate, mention names. color, object name, shape name, grouping the shape, color, function and size of objects using visual support methods.

\section{Results The ability to think logically in the Control and Experimental Group}

The ability to think logically is measured through observation in two groups (experiment and control), the ability to think logically can be carried out when the teacher conditions the child by positioning the children to sit comfortably, the teacher introduces all the pictures of various kinds of fruit by showing the labels on each of them. each image. Second stage on The teacher invites communication by showing pictures, the teacher divides into 3 groups, the teacher asks the children to name the objects shown by the teacher, asks the children to group pictures according to color, shape, size. The teacher invites the children to sort patterns based on color. The third stage, the two groups were observed again to measure the ability to think logically. The fourth stage here is the comparison of the mean value of the experimental group and the control group using a statistical analysis difference test.

This study gave the treatment only to the experimental group, for 12 days (12 times) so that the total treatment given was 12 times. The comparison of the average score for the ability to think logically in this study is as follows:

\begin{tabular}{|c|c|c|c|c|}
\hline Variable & Group & N & Mean & Information \\
\hline \multirow{2}{*}{$\begin{array}{c}\text { The ability to think logically } \\
\text { (Pre Test) }\end{array}$} & Control & 15 & 3.2847 & Very good \\
\cline { 2 - 5 } & Experiment & 15 & 3.4027 & Very good \\
\cline { 2 - 5 } & Total & 30 & 3.3437 & Very good \\
\hline \multirow{2}{*}{$\begin{array}{c}\text { The ability to think logically } \\
\text { (Post Test) }\end{array}$} & Control & 10 & 2.8780 & Well \\
\cline { 2 - 6 } & Experiment & 10 & 3.4770 & Very good \\
\cline { 2 - 5 } & Total & 20 & 3.1775 & Well \\
\hline
\end{tabular}

Table 3:- Control Group Logical Thinking Ability and Experiment

Source: Data processed by the author, 2020

Based on table 3, it is known that the results of the ability to think logically (post test) in the control group have an average value of 2.8780 which is in the category "Well" good logical thinking skills. While the results of the post-test logical thinking ability in the experimental group had a higher average value, amounting to 4.4770 which was included in the assessment of children having logical thinking skills in the "Very Good" category after doing visual support media.

Based on the data above, it can be seen that the average increase in the experimental group is greater than that of the control group, this is because the experimental group is treated in the form of visual support media that has been designed to develop children's logical thinking skills measured through the child's final ability to communicate, mention color names., object name, shape name, group the shape, color, function and size of objects using visual support methods.

The normality test is used to test whether the data is normally distributed or not. The normality test used the Kolmogorov-Smirnov formula. The following are the results of the normality test in this study. 
ISSN No:-2456-2165

\begin{tabular}{|c|c|c|c|}
\hline Variable & Class & $\begin{array}{c}\text { Kolmogorov } \\
\text { Smirnov }\end{array}$ & Significance \\
\hline Expressive language development (pretest) & \multirow{2}{*}{ Experiment } & 0.882 & 0.418 \\
\hline Expressive language development (posttest) & & 1,052 & 0.218 \\
\hline Expressive language development (pretest) & \multirow{2}{*}{ Control } & 1,194 & 0.116 \\
\hline Expressive language development (posttest) & & 0.639 & 0.809 \\
\hline Logical thinking skills (Pretest) & \multirow{2}{*}{ Experiment } & 0.684 & 0.737 \\
\hline Logical thinking skills (Posttest) & & 0.505 & 0.961 \\
\hline Logical thinking skills (Pretest) & \multirow{2}{*}{ Control } & 0.985 & 0.286 \\
\hline Logical thinking skills (Posttest) & & 0.683 & 0.740 \\
\hline
\end{tabular}

Table 4:- Normality Test Results

Source: Author processed data, 2020

The normality test in this study used the KolmogorovSmirnov formula. If the Kolmogorov Smirnov value < significance, the conclusion is that the data are not normally distributed. However, if the Kolmogorov Smirnov value > significance, the data is normally distributed. Based on table 4 above, all variables have a value of more than 0.05 , so it can be stated that all research variables have a normal distribution.
This homogeneity test is carried out to test the similarity of several different samples. In this study, researchers used the Levene's Test formula, by looking at the significance level of the Levene $F$ count. If the calculated Levene $\mathrm{F}$ value shows a significance level of more than 0.05 , it can be said that there is no difference in variance between sample groups or in other words the variance between groups is the same.

\begin{tabular}{|c|c|c|c|}
\hline Variable & Class & $\begin{array}{c}\text { Score } \\
\text { Significance }\end{array}$ & Level \\
\hline \multirow{2}{*}{ Expressive language development (pretest) } & Experiment & 0.060 & \multirow{2}{*}{0.05} \\
\cline { 2 - 2 } Expressive language development (posttest) & Control & Experiment & 0.05 \\
\cline { 2 - 2 } & Control & 0.128 & 0.05 \\
\hline Logical thinking skills (Pretest) & Experiment & 0.329 & \multirow{2}{*}{0.05} \\
\hline Logical thinking skills (Posttest) & Control & 0.196 & \\
\cline { 2 - 2 } & Control & & \\
\hline
\end{tabular}

Table 5:- Homogeneity Test Results

Source: Data processed by the author, 2020

Table 5 above is the homogeneity test data using the $5 \%$ significance level, namely 0.05 . The conclusion is, if the significance value is $<0.05$, the variant of the data group is not homogeneous, and if the significance value is $>0.05$, the variant of the data group is homogeneous. Based on the table above, all variables have homogeneous data variants.
Hypothesis testing in order to answer the problem formulations and hypotheses proposed in this study. Hypothesis testing used in this study is to use the $t$ test.The $t$ test is needed to partially test the significance level between each independent variable's influence on the dependent variable.

\begin{tabular}{|c|c|}
\hline Variable Expressive language development & Average value \\
\hline Post test Control group & 3,0400 \\
\hline Post test Experiment group & 3,7000 \\
\hline F-Count & 4,948 \\
\hline Significance & 0.039 \\
\hline
\end{tabular}

Table 6:- First Hypothesis Test Results

Source: Data processed by the author, 2020.

The calculation results in table 6 show that the average value of children's expressive language development in the control group is 3.0400 (Good), while the average value of expressive language development in the experimental group is 3.7000 (Very Good), from this average value, is relative It can be said that there are differences in children's expressive language development from the control group and the experimental group, reinforced by the results of the $\mathrm{F}$ test, namely the value of
Fcount $=4,948$ with a significant level (sig) of less than $5 \%$.This proves that there is a significant difference in children's expressive language development between the control group and the experimental group in other words there is a significant influence between visual support media on expressive language development in Kindergarten children group A inclusion schools Sidoarjo District Sidoarjo Regency so that the first hypothesis has proven. 
ISSN No:-2456-2165

\begin{tabular}{|c|c|}
\hline Variable Children's logical thinking ability & Average value \\
\hline Post test control group & 2.8780 \\
\hline Post test Experiment group & 3.4770 \\
\hline F-Count & 5,024 \\
\hline Significance & 0.038 \\
\hline
\end{tabular}

Table 7:- Second Hypothesis Test Results

Source: Data processed by the author, 2020

So that there is a difference in the ability to think logically through visual support media for children in the 4 - 5 year age group in Kindergarten A, inclusion school, Sidoarjo District, Sidoarjo Regency from the control group and the experimental group, strengthened by the results of the $\mathrm{F}$ test, namely the value of Fcount $=5.024$ significant (sig) less than $5 \%$. This proves that there are differences in the ability to think logically through visual support media for children aged 4 - 5 years in Kindergarten group A, inclusive schools, Sidoarjo District, Sidoarjo Regency which is significant between the control group and the experimental group in other words "There is a significant effect. between visual support media for the ability to think logically in Kindergarten group A children in inclusive schools, Sidoarjo District, Sidoarjo Regency ",

\begin{tabular}{|l|c|c|}
\hline \multicolumn{2}{|c|}{ Variable Expressive language development and ability to think logically } & Average value \\
\hline \multirow{2}{*}{ Expressive language development } & Post test control group & 3,0400 \\
\cline { 2 - 3 } & Post test Experiment group & 3,7000 \\
\hline \multirow{2}{*}{ Children's logical thinking skills } & Post test Experiment group & 2.8780 \\
\cline { 2 - 3 } & Willkss Lambada & 3.4770 \\
\hline \multicolumn{2}{|c|}{ F-Count } & 5.604 \\
\hline Significance & 5,584 \\
\hline
\end{tabular}

Table 8:- Third Hypothesis Test Results

Source: Data processed by the author, 2020.

Based on table 8 , the results of testing the third hypothesis show that the value of $\mathrm{F}$-count $=5,584$ or willkss'lamba is 0.604 with a significant level of 0.014 . The significant level obtained from the test results is less than $5 \%$ proves that there is a significant influence between visual support media on expressive language development and the ability to think logically in Kindergarten group A inclusion schools Sidoarjo District, Sidoarjo Regency so that the third hypothesis can be accepted.

\section{DISCUSSION}

Visual Support Media Influences the Development of Expressive Language of Children aged 4-5 Years in Inclusion Kindergarten, Sidoarjo District

Based on the results of the observations it is proven that there is influence of visual support media on the development of expressive language in children aged 4-5 years Kindergarten Inclusion of Sidoarjo District, Sidoarjo Regency. The proof of this hypothesis is supported by the difference in the average value of expressive language development in the control group of 3.0400 (Good), while the average value of expressive language development in the experimental group is 3.7000 (Very Good), this proves that there is a significant influence between Visual support media for the development of expressive language in Kindergarten group A children in inclusive schools, Sidoarjo District, Sidoarjo Regency.
As proof of whether Visual support media influences the development of children's expressive language, so the test is carried out ANOVA (Analysis of Variance), in this case the data analyzed is the Post-test data in the experimental group and the control group. Based on the ANOVA (Analysis of Variance) test, it was obtained that the value of Fcount $=4,948$ and a significant value of 0.039 , this proves that there is a significant influence between visual support media on expressive language development in Kindergarten children group A, inclusive schools, Sidoarjo District, Sidoarjo Regency.

Visual support media that have been applied to children Kindergarten ages 4 - 5 years old in Sidoarjo District, Sidoarjo Regency in influencing children's language development in terms of language, this is in line with the opinion of Hayes (2010) explaining that visual support is what we see everyday to support communication, such as language. body or body gesture. It can also be a medium that is created to support individuals who may have difficulty understanding something, so that visual support is used to represent daily needs.

Visual media can improve the development of expressive language for early childhood as stated in Permendikbud No.137 of 2013 on the standard level of development in understanding the language of children aged 4-5 years, namely expressive language. Through expressive language, children can say familiar words, answer questions, and repeat simple sentences. This is in accordance with Sugono in Dhieni (2006) which states that spoken language or expressive language is the language 
produced by using speech tools with phonemes as the basic elements. Oral language includes aspects of pronunciation, grammar (akat form and sentence structure), and vocabulary.

Visual Support Media Influences the Logical Thinking Ability of Children aged 4-5 Years in Inclusion Kindergarten, Sidoarjo District

The observations proved that the influence of visual support media on logical thinking skills of children aged 45 years atKindergarten Inclusion of Sidoarjo District, Sidoarjo Regency. The acceptance of the second hypothesis in the study can be seen from the difference in the average value of the ability to think logically in the control group of 2.8780 (Very Good) while the average value of the ability to think logically in the experimental group is 3.4770 (Very Good), this proves that there is a significant influence. Significant between visual support media for expressive language development and the ability to think logically in Kindergarten group A inclusion schools Sidoarjo District, Sidoarjo Regency.

Proof of what Visual support media affects the logical thinking skills of children aged 4-5 years, so the test is carried out one way ANOVA (Analysis of Variance), in this case the data analyzed is Post test data in the experimental group and the control group. Based on the one way ANOVA (Analysis of Variance) test, it was obtained that the value of Fcount $=5.024$ and a significant value of 0.038 , this proves that there is a significant influence between visual support media on expressive language development and the ability to think logically in Kindergarten group A inclusion schools Sidoarjo District, Sidoarjo Regency.

Visual support media that have been applied to children Kindergarten aged 4 - 5 years in Sidoarjo District, Sidoarjo Regency affects children's logical thinking skills.Visual support media through the theme of equivalent plants children can think logically through the activity of mentioning the names of fruits, colors, and sizes in pictures fruit.

This is in accordance with the opinion of Suminah (2015) that thinking logically is recognizing various differences, classifications, patterns, taking initiative, planning, and recognizing cause and effect which is translated into basic competencies and recognizes the objects around them (names on, colors, shapes, sizes, patterns, properties, sounds textures, functions, and other characteristics), conveying what and how the objects around it are familiar (name on, color, shape, size, pattern, properties, sound, texture, function and other characteristics) through various masterpiece.
Based on the research above, it can be concluded thatVisual support media can develop logical thinking skills in children aged 4-5 years Kindergarten Inclusion, Sidoarjo District, Sidoarjo Regency and proves that there is a significant influence between visual support media on the ability to think logically in children Kindergarten A inclusive school, Sidoarjo District, Sidoarjo Regency.

Visual Support Media Affects the Development of Expressive Language and Logical Thinking Ability in Inclusion Kindergarten, Sidoarjo District

The purpose of this next study was to determine the effect of the make a match model assisted by video media on student learning outcomes. The analysis of the research results in chapter IV shows that there is a greater influence on the experimental class using the make a match model assisted by video media compared to the control class learning using conventional learning.

The third objective in this study is to determine the effect Visual support media for the development of expressive language and logical thinking skills of children together. Based on the results of testing the third hypothesis in this study using analysis techniquesMultivariate Analysis of Variance (MANOVA) obtained results, namely where the $\mathrm{F}$ value has a significant value or a $\mathrm{P}$ value of 0.004 is greater than $5 \%(\mathrm{sig}<5 \%)$ then $\mathrm{H} 0$ is rejected and $\mathrm{H} 1$ is accepted, which means that the variable Expressive language development and logical thinking ability through visual support media for children aged $4-5$ years in kindergarten group A inclusion school, Sidoarjo District, Sidoarjo Regency.

The observations proved that simultaneous influence of visual support media on the development of expressive language and logical thinking skills of children aged 4-5 years inKindergarten Inclusion of Sidoarjo District, Sidoarjo Regency. The proof of this hypothesis is supported by the significant influence between visual support media on expressive language development and the ability to think logically in Kindergarden group A, inclusion school, Sidoarjo District, Sidoarjo Regency.

Visual support media are all media that only use the function of the visual sense to improve understanding and strengthen students' memory of learning material. Visual media can improve the development of expressive language for early childhood as stated in Permendikbud No.137 of 2013 on the standard level of development in understanding the language of children aged 4-5 years, namely expressive language. Through expressive language, children can say familiar words, answer questions, and repeat simple sentences. This is in accordance with Sugono in Dhieni (2006) which states that spoken language or expressive language is the language produced by using speech tools with phonemes as its basic elements. Oral language includes aspects of pronunciation, grammar (akat form and sentence structure), and vocabulary. 


\section{CONCLUSIONS AND SUGGESTIONS}

\section{Conclusion}

Based on the research that has been carried out and the difference test with Analysis of Variance (ANOVA) and Multivariate Analysis of Variance (MANOVA), it is concluded that: (1) There is an effect of visual support media on the development of expressive language in Kindergarten children, inclusion schools, Kecamatan Sidoarjo, Sidoarjo Regency; (2) There is an effect of visual support media on the ability to think logically in Kindergarten children, Sidoarjo District, Sidoarjo Regency; (3) There is an influence of visual support media influencing the development of expressive language and the ability to think logically in Kindergarten children, Sidoarjo District, Sidoarjo Regency.

\section{Suggestion}

The results of the study are expected to be effective information and evaluation of learning for children aged 45 years related to this visual support media will help educators to learn in improving the development of expressive language and the ability to think logically more attractively and effectively.

The results of the study are expected to provide a variety of contributions to Kindergarten Inclusion Education regarding the Development of Expression Language and the Ability to Think Logically, as a measure of the stimulation of early childhood development and development. Other researchers are described as examining similar research using as a reference and a basis for conducting more comprehensive research on the development of expressive language and logical thinking skills in children aged 4-5 years through visual support media.

\section{REFERENCES}

[1]. Antari, K. Y., Putra, I. K. A., \& Abadi, I. B. G. S. (2016). Penerapan Model Pembelajaran Visual, Auditory, Kinestetik berbantuan Media Gambar untuk meningkatkan kemampuan Kognitif Konsep Bilangan. Jurnal Pendidikan Anak Usia Dini Undiksha, 4 (1), 111.

[2]. Arifin, Zaenal. (2008). Metodologi Penelitian Pendidikan. Surabaya : Lentera Cendikia.

[3]. Arikunto, S. (2010). Prosedur Penelitian Suatu Pendekatan Praktik. Jakarta: Rineka Cipta.

[4]. Arimbi, Y. D., Saparahayuningsih, S., \& Ardina, M. (2018). Meningkatkan Perkembangan Kognitif melalui Kegiatan Mind Mapping. Jurnal Ilmah Potensia, 3 (2), 64-71.

[5]. Ali, M \& Asrori, M. (2003). Psikologi Remaja. Jakarta : Bumi Aksara.

[6]. Brata, M. (2009). Pengembangan Kemampuan Berbahsa Melalui Metode Bercerita di TK Aisyiyah Tegalsari Bandungan Ngawi Tahun Pelajaran 2008/2009. Skripsi. Ngawi: Program Studi PAUD Fakultas Ilmu Pendidikan IKIP PGRI Ngawi
[7]. Creswell, J. W. (2012). Research design Pendekatan kualitatif, Kuantitatif dan. Mixed; Cetakan ke-2. Yogyakarta: Pustaka Pelajar

[8]. Choirunnisa Nirahma P., \& Ika Yuniar, C. (2012). Metode dukungan Visual Pada Pembelajaran Anak dengan Autisme. Jurnal Psikologi Klinis dan Kesehatan Mental, vol. 1 (2), 1-8

[9]. Daryanto. (2015). Media Pembelajaran. Bandung: Satu Nusa

[10]. Departemen Pendidikan Nasional, (2008). Pendekatan, Jenis dan Metode Penelitian Pendidikan. Jakarta: Direktorat Tenaga Kependidikan, Direktorat Jendral Peningkatan Mutu Pendidik dan Tenaga Kependidikan

[11]. Dhieni, N. (2013). Metode Pengembangan Bahasa, Edisi 1. Jakarta : Universitas Terbuka.

[12]. Fatwikiningsih, N. (2014). Peningkatan Kemampuan berbahasa melalui metode Berkomunikasi dengan gambar pada Anak dengan ciri gangguan pemusatan dan Hiperaktivitas. Jurnal Sains dan Praktik Psikologi, 2 (3), 226 - 242.

[13]. Hayes, R. G., Hirano, S., Marcu, G., Monibi, M., Nguyen, H. D., \& Yeganyan, M. (2010). Interactive Visual Supports for Children with Autism. Focus on Autism and Other Developmental Disabilities. Personal and Ubiquitous Computing, 14, 663-680.

[14]. Hasan, Maimunah. (2009). PAUD (Pendidikan Anak Usia Dini). Jogjakarta: DIVA Press

[15]. Ilahi, Mohammad Takdir. (2013). Pendidikan Inklusi: Konsep dan Aplikasi. Jogjakarta: Ar-Ruzz Media

[16]. Jahja, Yudrik. (2013). Psikologi Perkembangan. Kencana. Jakarta.

[17]. Kurniah, Nina. (2012). Pengembangan Bahasa Program Magister Pendidikan Anak Usia Dini. Jakarta: Universitas Negri Jakarta.

[18]. Margono. (2010). Metodologi Penelitian Pendidikan. Jakarta: Rineka Cipta

[19]. Mustakin, M. N. (2005). Peranan Cerita dalam Pembentukan Perkembangan Anak TK. Jakarta: Departemen Pendidikan Nasional, Direktorat Jenderal Pendidikan Tinggi, Direktorat Pembinaan Pendidikan Tenaga Kependidikan dan Ketenagaan Perguruan Tinggi.

[20]. Okudo, A. R., \& Omotuyole, C. (2014). Enhanced Learning Environment and its Implications on the Preschool Children"s Language Performance. Europen Scientific Jurnal, vol. 10 (7), 405-413.

[21]. O’Neil, J. (1994). Can inclusion work? A Conversation With James Kauffman and Mara SaponShevin. Educational Leadership, 52 (4), 7-11

[22]. Otto, Beverly. (2010). Language Development In Early Childhood. New Jersey: Jearson Education.

[23]. Purwanto. (2008). Metodologi Penelitian Kuantitatif. Yogyakarta: Pustaka Pelajar

[24]. Permendiknas RI. (2009). Pendidikan Inklusi Bagi Peserta Didik yang Memiliki Kelainan dan Memiliki Potensi Kecerdasan dan atau Bakat Istimewa. Diambil kembali dari Permendiknas no 70 tahun 2009: http://peduliinklusif.blogspot.com 
[25]. Sa'ida, N. (2018). Bahasa Sebagai Salah Satu Sistem Kognitif Anak Usia Dini. Pedagogi: Jurnal Anak Usia Dini dan Pendidikan Anak Usia Dini, 4 (2), 16-22.

[26]. Santrock, J. W. (2008). Perkembangan Anak. Edisi Kesebelas Jilid I. Jakarta : Erlangga.

[27]. Santrock, J. W. (2008). Psikologi Pendidikan. Edisi Kedua. Jakarta : Kencana Prenada Media Group.

[28]. Slameto. (2015). Belajar dan Faktor-Faktor yang Mempengaruhinya. Jakarta: Rineka Cipta.

[29]. Siti, Aisyah. (2007). Perkembangan Dan Konsep Dasar Perkembangan Anak Usia Dini. Jakarta: Universitas Terbuka.

[30]. Smith, J. D. (2014). Sekolah Inklusi. Bandung: Penerbit Nuansa Cendekia.

[31]. Suardiman, S. P. (2003). Metode Pengembangan Daya Pikir dan Daya Cipta untuk Anak Usia Dini. Yogyakarta: FIP UNY.

[32]. Sugiyono. (2014). Metode Penelitian Pendidikan Pendekatan Kuantitatif, Kualitatif dan $R \& D$. Bandung: Alfabeta.

[33]. Suhartono. (2005). Pengembangan Keterampilan Bicara Anak Usia Dini. Jakarta: Depdiknas.

[34]. Sujiono, Y. N. (2010). Metode Pengembangan Kognitif. Jakarta: Universitas Terbuka

[35]. Sujiono, Y. N. (2013). Konsep Dasar Pendidikan Anak Usia Dini. Jakarta : Indeks

[36]. Sukardi. (2003). Metodologi Penelitian Pendidikan Kompetensi dan Prakteknya. Jakarta: Bumi Aksara.

[37]. Sukmadinata, N. S. (2010). Metode Penelitian Pendidikan. Bandung: PT Remaja Rosdakarya.

[38]. Sumarsono, Sonny. (2004). Metode Riset Sumber Daya Manusia. Yogyakarta: Graha Ilmu

[39]. Suminah, Enah. (2015). Kerangka Dasar dan Struktur Kurikulum 2013. Jakarta: Direktorat Pembinaan Pendidikan Anak Usia Dini

[40]. Susanto, Ahmad. (2014). Perkembangan Anak Usia Dini Pengantar dalam Berbagai Aspeknya. Jakarta: Prenada media Group

[41]. Suyadi. (2010). Psikologi Belajar Pendidikan Anak Usia Dini. Yogyakarta: Pedagogia.

[42]. Stainback, W., \& Sianback, S. (1990). Support Networks for Inclusive Schooling: Independent Integrated Education. Baltimore: Paul H. Brooks.

[43]. Yusuf, Munawir. (2005). Pendidikan Bagi Anak dengan Problema Belajar. Jakarta: Departemen Pendidikan Nasional. 